\title{
Conspicuous Absence of Independent Judiciary and 'Apolitical' Courts in Modern Ethiopia
}

Simeneh Kiros Assefa *

\begin{abstract}
Ethiopia had revolutions in 1974 and 1991, after which the Provisional Military Administration Council ('PMAC') and Ethiopian Peoples' Revolutionary Democratic Front ('EPRDF') governments came to power, respectively. Each incoming government re-established and re-structured the courts. Likewise, criminal jurisdictions of the courts and the rules of appointment of judges and court personnel were changed. Yet, the governments presented the courts as independent, insulated from political interference. After examining the respective legislation and the decisions of two sets of courts, I argue that Ethiopia never had an independent judiciary; there were courts established for dispute settlement for the ordinary citizen. The courts were not as apolitical as claimed by the respective governments. They have been, often, compliant with the interests of the regime of the day by giving effect to the executive's excesses of power or by creating enabling conditions, as though they were extension of the executive.
\end{abstract}

\section{Key terms:}

Ethiopian Courts $\cdot$ Judiciary $\cdot$ Modernisation of courts $\cdot$ Apolitical judiciary · Judicial independence

DOI http://dx.doi.org/10.4314/mlr.v15i2.3

This article is licensed under a Creative Commons Attribution-

NonCommercial-NoDerivs (CC BY-NC-ND)

Received: 1 May 2021

Accepted: 21 December 2021

\section{Suggested citation:}

Simeneh Kiros Assefa (2021), 'Conspicuous Absence of Independent Judiciary and 'Apolitical' Courts in Modern Ethiopia', 15(2) Mizan Law Re view: 379-418

\footnotetext{
- Simeneh Kiros Assefa (PhD), Associate Professor of Law, Addis Ababa University School of Law, member of Ethiopian Bar and California State Bar (inactive).

E-mail: simeneh@simenehlaw.com.

ORCID: https://orcid.org/0000-0003-0915-9360

I am immensely grateful to helpful comments from Ato Tamiru Wondemagegnehu, Judge Bereket Seifu, Dr. Muradu Abdo, Ato Cherinet Hordofa, Dr. Girmachew Alemu and two anonymous reviewers. I also thank Ato Samuel Worku for his research assistance.
} 


\section{Contents}

Abstract

1. Introduction

2. Setting the Context of the Study

3. The Establishment of Modern Courts

3.1 Establishment of modern national courts

3.2 Re-structuring of the court relative to the federation of Eritrea with Ethiopia

3.3 Restructuring courts after the 1955 Revised Constitution

3.4 The last imperial re-structuring of courts

4. Courts under the Military Government

4.1 The regular courts

4.2 The establishment of Special Courts-Martial

4.3 The re-establishment of the special courts with civilian judges

4.4 The re-establishment of the supreme court as per the 1987 PDRE

Constitution

4.5 Observations regarding the Special Courts-Martial and the Special Court

4.6 Selected cases of the Special Court

5. Federalisation of Courts

5.1 De facto federalisation of courts under the Transitional Government

5.2 Federal courts under the FDRE Constitution

5.3 Selected cases of the Cassation Division

5.3.1 Binding interpretative decisions relating to bail

5.3.2 Interpretative decisions relating to objections to charges

5.3.3 Interpretative decisions relating to administrative decisions'

'finality clause'

6. Developments Relative to Federal Courts Proclamation No 1234/2021

7. Conclusion and the Way Forward

\section{Frequently used acronyms}

EPRDF Ethiopian Peoples' Revolutionary Democratic Front

FDRE Federal Democratic Republic of Ethiopia

PDRE Peoples Democratic Republic of Ethiopia

PMAC Provisional Military Administration Council

TGE Transitional Government of Ethiopia 


\section{Introduction}

In modern governance, the judiciary is the third branch of the state that controls the other two powerful branches. Its competence and independence are indispensable for its proper functioning. However, the history of modern governance in Ethiopia is short; the story of the court is even shorter. The court is not treated as the third organ; it is rather treated as an extension of the executive as a matter of fact and, until recently, as a matter of law.

Upon change of political power, incoming governments have been reestablishing the courts, redefining their jurisdiction, their rules of procedure, rules of appointment, tenure, and discipline of judges. Accordingly, important changes were made during the Imperial period when Eritrea was federated with Ethiopia. Later, when the Provisional Military Administration Council ('PMAC') came to power in 1974, Special Courts-Martial were established to try the Imperial Government officials. Major restructuring of the courts was made as per the 1987 Constitution of the People's Democratic Republic of Ethiopia ('PDRE Constitution').

Likewise, as soon as the Ethiopian Peoples' Revolutionary Democratic Front ('EPRDF') came to power in 1991, the foundations for a federal structure of the courts were laid down long before the inception of the FDRE Constitution. The respective governments, both in official statements and legislative rules asserted that courts are independent (from political forces and processes) while blaming the previous regimes for abusing justice. ${ }^{1}$

This article argues that Ethiopia never had an independent judiciary; there were only courts established for dispute settlement for the ordinary citizen; in the exercise of their criminal jurisdiction, they were utilised as state apparatus, as though they were extensions of the executive for suppressing political opposition or dissent. It examines the various legislation reestablishing and re-structuring the courts. It specifically examines the criminal jurisdiction of the courts, the rules of appointment, tenure and discipline of judges and court personnel. Judicial decisions (of the Special Court of the Provisional Military Administration Council operating between 1981 and 1987, and the Cassation Division of the Federal Supreme Court of Ethiopia operating since 1996) are reviewed.

\footnotetext{
${ }^{1}$ See for instance, The Independence of the Administration of Justice Proclamation No 23/1992 ('Proc No 23/1992') preamble. In the earlier days of PMAC, its Chairman Lt. Gen. Aman Andom made a statement implying independence of the Special CourtsMartial. 'Objectives of the Dergue', Addis Zemen, Addis Ababa, 13 September 1974 (in Amharic) 1, 3.
} 
As the criminal law is effective state social control mechanism, this article focuses on criminal jurisdiction of courts and their decisions on criminal matters. The next section sets the context to the discussion how courts in non-democratic regimes function. Section 3 dwells on the establishment and evolution of modern courts in the Imperial period. It illustrates how the political changes have also influenced the judicial structure. Section 4 dwells on the restructuring of courts in the military regime. It also examines interpretation and application of the (Revised) Special Penal Code by the Special Court. Section 5 deals with the restructuring of the court in the EPRDF era and reviews the decisions of the Cassation Division which are binding decisions in legal interpretation. Federal Supreme Court Cassation Division decisions on petitions against administrative decisions regarding access to court are also examined.

\section{Setting the Context}

In constitutional governance, the judiciary is the third branch of the state, at par with and controlling the other two. Constitutions are the documents which create the three branches of the state and defining their role in governance. In a non-constitutional, non-democratic state, there are often courts with limited jurisdiction. ${ }^{2}$ In the judiciary or in the courts, there is only one question that needs to be raised ${ }^{3}$-what is the role of the judge? The simplest answer is resolving disputes pending before the court. ${ }^{4}$ But this calls for two further questions: how does the judge resolve such disputes? Is dispute resolution the only role of the judge?

The answers to these two questions fairly overlap. The court resolves such disputes by applying the law. In applying the law, the court makes choices. Those choices include the determination of the law and the applicable rule, which also necessarily involve a choice of legal theory, and

2 Ethiopia did not have a constitution under the PMAC (1974-1987), but it had courts established by Special Courts-Martial Establishment Proclamation No 7 of 1974 ('Proc No 7/1974'), and by Administration of Justice Proclamation No 52/1975 ('Proc No $52 / 1975$ ').

${ }^{3}$ In this study, the words 'court' and 'the judiciary' are used to mean different things. 'Court' is used to refer to any institution for dispute settlement among the citizenry established in any form. The word 'judiciary' refers to the third branch of the state that does all activities enforcing the bill of rights and controlling the other branches of the state within their limit.

${ }^{4}$ Aharon Barak (2006), The Judge in a Democracy (Princeton UP) $307 \mathrm{ff}$. 
the method of interpretation of such rule. ${ }^{5}$ In resolving disputes, both the court and the judge are claimed to be free from interference. It is presented as a non-political organ. Even working under authoritarian regime, as in Nazi Germany, Apartheid South Africa ${ }^{6}$ former military dictatorships, such as Chile and Brazil, ${ }^{7}$ including our own Ethiopia, ${ }^{8}$ judges opine that they are apolitical while they are under repression. ${ }^{9}$ The definition of the political/apolitical is certainly founded on legal positivist perspectives. ${ }^{10}$ In this sense, 'political' is an adjective that describes those running for public office or those organs that are involved in the lawmaking process. ${ }^{11}$

However, irrespective of the applicable legal theory, the political nature of the court may be seen in two ways. Wojciech Engelking argues that if the political is legislative action, the judicial application of the law by the court is an extension of the legislative process. ${ }^{12}$ Judicial application of the law has both application of the law and lawmaking aspect. Aharon Barak further

${ }^{5}$ Simeneh Kiros Assefa (2020), 'Non-Positivist 'Higher Norms' and 'Formal'

Positivism: Interpretation of Ethiopian Criminal Law', 14 Mizan LR, at 66.

Lisa Hilbink (2007), Judges Beyond Politics in Democracy and Dictatorship: Lessons from Chile (Cambridge UP) $31-33$.

Hans Petter Graver (2015), Judges Against Justice: On Judges When the Rule of Law is Under Attack (Springer) 208 - 212, 221.

Barak, 'The Judge' (supra note 4) 106 - 107, 117 - 121.

EW Thomas (2005), The Judicial Process: Realism, Pragmatism, Practical Reasoning and Principles (Cambridge UP) $7-22$.

${ }^{6}$ Graver, supra note 5, at $53 \mathrm{ff}$.

${ }^{7}$ See for example, Anthony W Pereira (2008), 'Of Judges and Generals: Security Courts under Authoritarian Regimes in Argentina. Brazil, and Chile' in Tom Ginsberg and Tamir Mustafa (eds), Rule by Law: The Politics of Courts in Authoritarian Regimes (Cambridge UP) $23 \mathrm{ff}$.

${ }^{8}$ Simeneh 'Higher Norms', supra note 5.

${ }^{9}$ Graver, supra note 5, 39 - 45.

10 Wojciech Engelking (2019), 'The Political Character of the Judiciary: Schmitt, Kelsen and the Polish Constitutional Tribunal' in Martin Belov (ed), The Role of Courts in Contemporary Legal Orders (Eleven International Publishing) 386 - 389. Simeneh Kiros Assefa (2020), 'Limiting Criminalisation Power of the State in Ethiopia' (PhD dissertation submitted to Addis Ababa University Law School, unpublished) 137-139.

${ }^{11}$ Mauro Zamboni (2008), Law and Politics: A Dilemma for Contemporary Legal Theory (Springer) 61-63.

${ }^{12}$ Luc J Wintgens (2002), 'Legislation as an Object of Study of Legal Theory: Legisprudence' in Luc J Wintgens (ed), Legisprudence: A New Theoretical Approach to Legislation (Hart Publishing) 11-13. 
argues that in common law, it is evident that the court is making the law ${ }^{13}$ through case laws in addition to the statutes enacted by the legislature. The fate of statutory law is not any different because the statute before and after the decision is entirely different. ${ }^{14}$ Although the binding interpretative decision of the Cassation Division of the Federal Supreme Court ${ }^{15}$ cannot be considered as lawmaking (as in case laws in common law jurisdictions), the binding nature of its legal interpretation (for cases that invoke the same legal provision, identical issues and comparable facts) in its decisions is clear.

Barak opines that, in a democracy, the role of the judge is to bring law and society closer as well as to protect and defend democracy and rule of law. ${ }^{16}$ Barak admits such assertion presupposes the judiciary as a third branch of the state. However, whether a democratic or otherwise nature of the state, where the decision of the court has implication on political power, even the selection and appointment of the judges is a political decision. ${ }^{17}$ This is because, even when courts are established only as dispute settlement organs, there are instances where courts are used by the executive as in the case of administration of criminal justice which, by its very nature, is political. ${ }^{18}$

The criminal law, as mentioned earlier, is the most effective state social control devise that is used for the prevention of crime. However, the 'greater

${ }^{13}$ Thomas, supra note 5.

${ }^{14}$ Aharon Barak (2012), Proportionality: Constitutional Rights and their Limitations (Doron Kalir tr, Cambridge UP).

${ }^{15}$ Federal Courts Proclamation Re-amendment Proclamation No 454/2005, art 2(4).

${ }^{16}$ Barak 'The Judge' (supra note 4). For instance, the US Supreme Court in Marbury $v$ Madison 5 U.S. 137 (1803) had defined its jurisdiction. In the $20^{\text {th }}$ century, exercising its self-defined jurisdiction, it expanded the scope of civil rights in the criminal process, such as in Miranda v Arizona 384 U.S. 333 (1966), Mapp v Ohio 367 U.S 497 (1961), Escobedo v Illinois 378 U.S. 478 (1964), Beck v Ohio 379 U.S. 89 (1964), Brady v Maryland 373 U.S. 726 (1963), Ker v California 374 U.S. 23 (1963), Katz v United States 389 U.S. 347 (1967).

${ }^{17}$ Engelking supra note 10. Also see Graver (n 5) 45 - 46. The US Supreme Court nomination is a highly contentious issue in the US. See "Supreme Revenge" a documentary made by the American Public Broadcasting Services on conflicts in the Senate between the two parties at $<$ https://www.youtube.com/watch?v=1Yt2xUJfdyw $>$ last accessed on September 23, 2021.

${ }^{18}$ For in-depth discussion on how the criminal law is used in the Ethiopian criminal process, see Simeneh Kiros Assefa and Cherinet Wordofa Wetere 'Governing Using Criminal Law: Historicising the Instrumentality of Criminal Law in Ethiopian Political Power' (forthcoming in 32 J Eth L). 
good' is perverted and the individual is subjected to 'the good of society' which unjustifiably expands the realm of the criminal law. ${ }^{19}$ The government makes laws that are 'excessive' or 'harsh'. And the government uses (desires to use) the court as an extension of the executive to enforce such laws that are contrary to certain 'higher principles'. ${ }^{20}$ The courts in such regimes, find themselves in a dilemma between enforcing the black letters of the law adopted by such authoritarian regimes or refuse to enforce such 'unjust laws' based on a higher principle. ${ }^{21}$ That is why, at times, the debate necessarily involves legal theory. ${ }^{22}$

The political nature of the courts and their operations should now be clear. What is not clear is the magnitude of the political nature of the court. In order to better appreciate the extent of the political nature of the courts, one needs to see the context judges and courts in Ethiopia work. There are four major issues which appear overlapping but conceptually distinct. First, for the most part, Ethiopia was ruled without a constitution; ${ }^{23}$ the courts were, thus, established by sub-constitutional norms. The courts were established as dispute resolution fora for the citizenry, not as judiciary at par and in control of the other two branches of the state. The re-establishment and re-structuring of the court often related to criminal jurisdiction because the criminal law is effective social control mechanism used by the state.

Second, in the absence of a constitution until 1931, there was no legally set limit to the power of the government other than such power being exercised by the government benevolently. Even after 1931, lack of the democratic process was reflected in the establishment of courts created by a monarch or group of persons (PMAC/ the Dergue) or TGE (Transitional

19 The central justification of continental criminal law the doctrine of 'legal good' or 'common good'. Santiago Mir Puig (2008), 'Legal Goods Protected by the Law and Legal Goods Protected by the Criminal Law, as Limits to the State's Power to Criminalize Conduct' $11 \mathrm{New}$ Crim Law Rev: An International and Interdisciplinary Journal, pp. 410-112. Markus D Dubber (2005), 'Theories of Crime and Punishment in German Criminal Law', 53 Am J Comp L, pp. 684-686. Simeneh 'Limiting Criminalisation', supra note 10, at 34-36.

${ }^{20}$ Simeneh 'Higher Norms', supra note 5, at 67-69.

${ }^{21}$ Graver supra note 6, at 5-7.

${ }^{22}$ See for instance, Roberty Alexy (2021), Law's Ideal Dimension (Oxford UP). Robert Alexy (2002), Argument from Injustice: A Reply to Legal Positivism (Bonnie Litschewski Paulson and Stanley L. Paulson tr., Clarendon Press).

${ }^{23}$ See Simeneh and Cherinet 'Governing' supra note, 18. 
Government of Ethiopia) which were not democratically elected. The fate of the courts was, thus, at the mercy of those at the helm of power.

Third, there was no bill of rights on which claims may be based and that limits the power of governments on the basis of which the court could hold the other two branches to account for their actions. Even the 1995 FDRE Constitution does not empower courts with judicial review which limits their functions thereby rendering them unable to control the other two branches. Nor can the judiciary consistently and effectively implement the bill of rights embodied in the FDRE Constitution, mainly because of the timidity of courts. $^{24}$

Often, courts in authoritarian regimes, not just in Nazi Germany and Apartheid South Africa, but in former military dictatorships, such as Argentina, Brazil and Chile ${ }^{25}$ and the former socialist Soviet Union ${ }^{26}$ were compelled to comply with the demands of the government; in some instances, those judges may even be complicit to the repression of authoritarian regimes. ${ }^{27}$

In an effort to understand the predicaments of judges in authoritarian political systems, Lisa Hilbink examines judicial structure and ideology in such regimes. She offers explanation for complicity of judges with authoritarian regimes ${ }^{28}$ which can fall under two categories, i.e., regime related and attitudinal.

The regime related explanation relates to the direct involvement of the regime in judicial decision-making. This is manifested through designing the structure of the court that is palpable to the regime, restriction of jurisdiction of the court, strictly controlled recruitment, appointment, promotion and discipline of judges. There is always formal independence of both the court as an institution and the judges personally. For instance, the Special Courts-

${ }^{24}$ The court believes enforcement of the constitution involves interpretation which is left to the House of Federation (HoF) and the Council of Constitutional Inquiry (CCI). Simeneh Kiros Assefa (2010), Criminal Procedure Law: Principles, Rules and Practices (Xlibris) $64 \mathrm{ff}$.

25 See for example, Tamir Moustafa and Tom Ginsburg (2008), 'Introduction: The Functions of Courts in Authoritarian Politics' in Tom Ginsburg and Tamir Moustafa, Rule by Law: The Politics of Courts in Authoritarian Regimes (Cambridge UP) $4 \mathrm{ff}$.

${ }^{26}$ Kazimierz Grzybowiski (1960), 'Main Trends in The Soviet Reform of Criminal Law' 9 Am Univ LR.

${ }^{27}$ Graver supra note 5, at 205.

${ }^{28}$ Hilbink offered four explanations: regime related explanation, the attitudinal explanation, the class-based explanation and the legal theory explanation. Hilbink supra note 5 , at $27-33$. 
Martial Establishment Proclamation article 12(1) provides that '[j]dges shall be completely independent in the exercise of their functions, and in the administration of justice, they shall submit to no other authority than that of the law' ${ }^{29}$ The Transitional Government of Ethiopia had adopted a separate statute, Independence of the Administration of Justice Proclamation No 23/1992. However, judges were often handpicked and appointed either because of personal acquaintance or party affiliation. ${ }^{30}$ In spite of such laws, judicial administration was still under the watchful eyes of the government. ${ }^{31}$

The attitudinal explanation refers to the social role of courts. This relates to the choice the judges made, either to stick to the letters of the law in order to remain 'apolitical', or refuse to enforce such 'unjust' laws based on higher principles, such as justice and rule of law. ${ }^{32}$ This can better be seen in the context of legal theory and methodology. ${ }^{33}$ Although the law claims higher principles, such as natural law, customs, human conscience for its legitimacy, ${ }^{34}$ the judges limit themselves to the black letters of the law, at times, in full disregard of the basic methods of interpretation. ${ }^{35}$ Often, it is positivism that is blamed for the political wrongs, and blundering justice. ${ }^{36}$ The judges interpret the law and the facts in so far as it is 'convenient'. In such a situation, the choice of a particular legal theory and a particular

29 Special Court Establishment Proclamation No 215/1981 ('Proc No 215/1981') art 9. Supreme Court Establishment Proclamation No 9/1987 ('Proc No 9/1987') art 7.

30 The PMAC Special Courts-Martial judges were members of the army; the EPRDF judges were for the most part party-affiliated or had proven themselves in other responsibilities particularly those in the leadership and administrative role.

31 Judicial Administration Proclamation No 323/1973, art 4. Proc No 9/1987 (supra note 29) arts 27 cum 21(1); Proc No 23/1992 supra note 1, art 8; Federal Judicial Administration Commission Establishment Proclamation No 24/1996 art 4. Also see Ethiopian Human Rights Council Report that judges were suspended because they were allegedly belonging to the former regime.

${ }^{32}$ Hilbink supra note 5, at 5-7.

${ }^{33}$ Ibid. Graver supra note 5.

${ }^{34}$ Special Penal Code Proclamation No 8 of 1974 ('Proc No 8/1974') preamble, paras 9-11.

${ }^{35}$ See Simeneh Kiros Assefa (2017) 'Methods and Manners of Interpretation of Criminal Norms', 11 Mizan LR, Simeneh 'Higher Norms' supra note 5.

${ }^{36}$ Ugo Mattei and Laura Nader (2008), Plunder: When the Rule of Law is Illegal (Blackwell Publishing). 
method of interpretation of the law is a matter of politics. ${ }^{37}$ The 'apolitical' claim of judges in an authoritarian regime is thus a mere farce. ${ }^{38}$

\section{The Establishment of Modern Courts}

\subsection{Establishment of modern national courts}

We can focus on developments since 1942 for convenience. There were courts, prisons and the police before $1942,{ }^{39}$ and the 1931 Constitution had embodied five provisions (Articles 50 to 54) on the judiciary. Chapter 5 of the sub-constitutional rule (adopted on the same date as the 1931 Constitution) provided that the country is divided into 14 provinces, which were further divided into Awradja and Woreda. ${ }^{40}$ The Governors of the provinces were required to establish offices such as the municipality, a court, and offices relating to services including health and education. ${ }^{41}$ The functions of the judiciary were provided for under Chapter 9. Articles 77 and 78 provided that the Minster of Justice would draw up legislation regarding the determination of the number of judges, appointment of Awraja judges, appeal, the jurisdiction of the King's Court, whether hearing would be held in public or otherwise, among others, and through the two Houses present such draft to the Emperor.

After the Negarit Gazeta was established as official legal gazette (in 1942), the Supreme Imperial Court, the High Court, the Provincial Courts and Regional or Communal Courts were established by Administration of Justice Proclamation No 2 of $1942 .{ }^{42}$ The lack of skilled judges for such

${ }^{37}$ Graver supra note 5.

${ }^{38}$ It is rather argued that an apolitical judiciary is 'far better suited to authoritarianism than to democracy': Hilbink, supra note 5 at 8. Zamboni supra note 11, 130.

39 See Getahun Mesfin Haile (2012) 'Urbanisation, Centralisation, and the Rise of Modern Incarceration Regime in Ethiopia: Some Notes toward a History of the Dire Dawa Prison', 45 J of Eth Studies; Semeneh Ayalew 'A History of Kerchele, 1974 1991' (Addis Ababa University, unpublished MA thesis, 2004) cited in Alex de Waal and Rachel Ibreck (2013) 'Alem Bekagn: The African Union's Accidental Human Rights Memorial', 112 African Affairs, p. 196.

40 Art 42 of the sub-constitutional rule adopted in July 1931 on the same day the Constitution was adopted. Blatangeta Mahteme Selassie Woldemeskel (1942 EC), Zikre Neger, Second Ed., $777 \mathrm{ff}$.

${ }^{41}$ Id., art 48.

42 Administration of Justice Proclamation No 2 of 1942 ('Proc No 2/1942') art 2. The Police was established by Police Proclamation No 6 of 1942 and Police (Addis Ababa) Proclamation No 7 of 1942; the public prosecution was established as per the 
courts had clearly been reflected in the arrangement of the courts. First, both the Supreme Imperial Court and the High Court of Ethiopia had their seats in Addis Ababa. And the Supreme Imperial Court was constituted by the Afe Negus, two judges from the High Court, provided such judges did not see the case earlier. ${ }^{43}$

The High Court comprised such number of judges as found to be necessary from time to time as recommended by the Minister of Justice. ${ }^{44}$ The High Court had 'full criminal and civil jurisdiction in Ethiopia' and adjudicated in any part of the country as was convenient for the hearing and was constituted by three judges. ${ }^{45}$

A Provincial Court that was established in every Province had one of the judges as the President of such Court. ${ }^{46}$ It had both criminal and civil jurisdiction as well as appellate jurisdiction from the decision of a Regional or Communal Court. ${ }^{47}$ This was probably the first time civil and criminal jurisdiction were separately provided for except one division of the court established in 1926 in Addis Ababa to deal with some serious crimes. ${ }^{48}$

Modern Administrative Structure

The Administrative Regulation Decree No 1 of 1942 created the administrative structure, which also had impacted the court structure because

Public Prosecutors Proclamation No 29 of 1942 and prisons were established as per Prisons Proclamation No 45 of 1944.

${ }_{43}$ Proc No 2/1942, supra note 42, arts 10 and art 3, respectively.

44 It also included British nationals as the Emperor decides. Ibid art 4. For further details, see Esubalew Belay Fanta (2016), 'The British on the Ethiopian Bench: 1942 -1944', 16 Northeast African Studies.

${ }^{45}$ Proc No 2/1942, supra note 42, arts 7-9.

46 Id., art 12. Administrative Regulations Decree No 1 of 1942 ('Decree No 1/1942') part 78. By the time these legislation were adopted there were no less than 70 provinces. Nathan Marein (1954), The Ethiopian Empire - Federation and Laws (Vurtheim and son) 28.

${ }^{47}$ The statute merely recognises the potential existence of such Regional or Communal Courts, as it would be established 'by a warrant' issued by the Emperor. ibid art 18 .

${ }^{48}$ In the Fiteha Negest, The Court Procedure Rules Legal Notice No 33 of 1943 applied in the High and Provincial Courts, and The Supreme Imperial Court Procedure Rules Legal Notice No 155/1955, there did not seem to be distinction regarding the process and the consequences in civil and criminal matters. Prince Teferi in 1926 established a division of a court to hear only serious criminal cases. Merse'Hazen WoldeQirqos (2008 EC), The Beginning of the Twentieth Century: Memories of My Eventful Days: From What I Saw and Heard 1896 - 1922, $3^{\text {rd }}$ Ed (title in Amharic), Addis Ababa University Press, 329-330. 
Governors had also been Presidents of the respective courts. There was thus a Governor-General for each province, under whom there was Governor for each Woreda. ${ }^{49}$ Courts were established for each Province and the GovernorGeneral was the President of such Provincial Court. ${ }^{50}$

There were three other judges appointed by the Emperor on the recommendation of the Minster of Justice, one of whom was the VicePresident of such court. The Governor-General was responsible to the Minister of Justice regarding his responsibilities in the administration of justice. ${ }^{51}$ Likewise, the Governor of a Wereda was the President of the Wereda Court. ${ }^{52}$ And the Mislenie was 'the President of the Court ... constituted in the Mislenie district. ${ }^{53}$

\section{Establishment of Local Courts}

Local judges (atbiya dagna) were appointed by virtue of the Establishment of Local Judges Proclamation No 90 of $1947^{54}$ to adjudicate both civil and criminal matters. The local judge would first attempt to compromise the parties and he would enter a judgement only where that was not possible, in criminal cases 'a fine not exceeding 15 dollars'.

\section{Courts for the Prosecution of Special Crimes}

The establishment of a special court as per the Security Proclamation No 87 of 1947 was meant to deal with 'treason, espionage and allied offence', committed during World War II. ${ }^{56}$ There is no record showing this division had been working other than a single event which involved Dejazmach Haile

${ }^{49}$ Decree No 1/1942 supra note 46, parts 1 and 9.

${ }^{50}$ Proc No 2/1942 supra note 42, art 2; Decree No 1/1942, supra note 46, part 78.

${ }^{51}$ Id., part 81.

${ }^{52}$ Id., part 82. Also see WEH Howard (1955), Public Administration in Ethiopia: A Study in Retrospect and Prospect (JB Wolters) 60 - 61.

53 Decree No 1/1942 (supra note 46) part 83; Howard (supra note 54) $61-62$. The already existing 'traditional' dispute settlement mechanisms would be maintained. Proc No 2/1942 supra note 42, art 23.

${ }^{54}$ Such judges would be selected by the Awraja Court President and the Vice-President in consultation with the elders of the community. Establishment of Local Judges Proclamation No 90 of 1947 ('Proc No 90/1947') art 6.

55 Proc No 90/1947 (supra note 54) art 3. Article 11 had also provided that the provisions of the Proclamation shall not affect 'the tradition of the Country in settling disputes by compromise.'

${ }^{56}$ The Special Court would be constituted of 9 judges, 4 of them were judges from the High Court of Ethiopia, 3 army officers not below the rank of Lieutenant Colonel, and 2 civil servants not blow the rank of Governor. 
Conspicuous Absence of Independent Judiciary and 'Apolitical' Courts in ... Ethiopia 391

Selassie Gugsa who was handed over by the British to be tried by such Court. $^{57}$

\section{Administrative Re-Structuring}

Administrative re-structuring was made based on Decree No 6 of $1946 .^{58}$ Moreover, the courts were re-structured by Proclamation No 102 of 1948. Accordingly, (a) the Teklay Ghizat Court; (b) the Awraja Ghizat Court; (c) the Woreda Court; and (d) the Mikitil-Woreda Ghizat Court were established. $^{59}$ Thus, the Provincial Courts became Teklay Ghizat Courts; ${ }^{60}$ and the Regional and Communal Courts became Awraja Courts. Woreda and Mikitil-Woreda Ghizat Courts were also created. ${ }^{61}$

\subsection{Re-structuring of the court relative to the federation of Eritrea with Ethiopia}

The federation of Eritrea to Ethiopia in 1952 was a major political change ${ }^{62}$ that demanded reform both in the law and institutions. ${ }^{63}$ The Supreme Imperial Court thus became the Federal Supreme Court, and a separate division of Federal High Court was established in Eritrea by virtue of the Federal Judiciary Proclamation of Ethiopia No 130 of $1953 .{ }^{64}$ The Imperial Supreme Court was considered as Federal Supreme Court, with the Afe Negus at its president, and it had two other judges one of whom was Eritrean. $^{65}$ This was made without affecting the jurisdiction of courts stipulated under the Administration of Justice Proclamation No 2 of 1942.

${ }^{57}$ Marein, supra note 46, at 74-76. There had also been a Security Court of Appeal established constituted by 5 judges: (1) the Afe Negus, (2) President of the Senate, (3) President of the Chamber of Deputies, (4) a person designated by the Emperor from the Crown Council, and (5) one designated by the Emperor from among highest ranking generals of the Imperial Army.

${ }^{58}$ Administrative Regulations (Amendment) Decree No 6 of 1946 art 1.

${ }^{59}$ Proclamation to Amend the Administration of Justice Proclamation, Proclamation No 102 of 1948 art 2.

${ }^{60}$ Id., art 4.

${ }^{61}$ Id., art 5.

${ }^{62}$ The Entry into Force of the Federation of Eritrea with Ethiopian Proclamation No 124/1952.

${ }^{63}$ Marein, supra note 46, 15 -16.

${ }^{64}$ The Federal Judiciary Proclamation of Ethiopia No 130 of 1953.

${ }^{65}$ Id., art 3. 
As part of the pact federating Eritrea with Ethiopia, Public Rights Proclamation No $139 / 1953$ was adopted. ${ }^{66}$ In order to protect the newly created Federation, the Federal Crimes Proclamation No 138 of 1953 was also adopted. The jurisdiction relating to violations of these laws was vested in the Federal Courts.

\subsection{Restructuring courts after the 1955 Revised Constitution}

Eritrea later became part of Ethiopia. After the adoption of the 1955 Revised Constitution, (a) the Woreda Court; (b) the Awradja Court; (c) the High Court; and (d) the Supreme Imperial Court ${ }^{67}$ were re-established by virtue of Courts Proclamation No 195 of 1962. The federal structure of courts was abolished. High Courts were set up 'permanently in each Teklay Guezat'. ${ }^{68}$ The number of judges sitting in a case was also changed.

In Woreda and Awradja Courts, cases are seen by one judge. However, Awradja Courts had three judges with regard to cases submitted to them on appeal from the Woreda Court. High Court and Imperial Supreme Court benches had three judges. ${ }^{69}$ Specialisation of jurisdiction of courts was introduced. While the Woreda and Awraja courts had criminal and civil jurisdictions, the High Court had jurisdiction on specialised subjects, such as the formation and dissolution of commercial organisations, negotiable instruments, bankruptcy, insurance and maritime, trademark and nationality issues. $^{70}$

According to Proclamation No 195/1962, 'law' was limited to those 'proclamations, decrees, orders and any subsidiary legislation published in Negarit Gazeta' deliberately disregarding traditional dispute settlement mechanisms. ${ }^{71}$ It further introduced modern court hearing processes, such as hearing in open court, removal of judges, contempt of court, and prohibition of appeal on interlocutory matters. ${ }^{72}$

${ }^{66}$ The 1955 Revised Constitution, unlike its predecessor, would contain a bill of rights replacing the Public Rights Proclamation.

${ }^{67}$ Courts Proclamation No 195 of 1962 ('Proc No 195/1962'), art 3(1).

${ }^{68}$ Id., art 3(2).

${ }^{69}$ Id., art 4(1).

${ }^{70} \mathrm{Id}$., arts 5 and 7.

${ }^{71}$ While the Amharic version is definitive, the English version does not give such impression. Id., art 2.

${ }^{72}$ Id., arts 12-21. It is worth noting that Ethiopia had already adopted the Criminal Procedure Code in 1961. 


\subsection{The last imperial re-structuring of courts}

The last Imperial period re-structuring of courts was made by Judicial Administration Proclamation No 323/1973 which had two major features. First, it established the Judicial Administration Commission and defined its powers. ${ }^{73}$ Second, it ended the functions of Governors as judges in their respective Governorate in an effort to introduce separation of powers. ${ }^{74}$

There are a few observations to be made regarding the Imperial Courts. First, the early years were marked by the establishment and progressive improvisation of both the institutions and norms. This period started with the introduction of modern court system in 1942 where judges sat in the different tiers of the higher courts ${ }^{75}$ while in the lower courts there was extensive overlapping between the executive and the judiciary. ${ }^{76}$ The system also had recognised the traditional dispute settlement ${ }^{77}$ to merely address the insufficiency of state laws, institutions, and skilled personnel befitting the newly created court structure (rather than due recognition to legal pluralism).

Eventually benches of courts expanded their reach and in some instances specialized in certain areas of the law thereby leaving out traditional dispute settlement mechanisms and they ultimately brought disputes fully in the realm of the state. ${ }^{78}$ The progressive 'modernisation' of the court structure and functioning made it appear a public institution rendering justice as a public service. The circle got closer to completion when the court was (an institution) physically separated from the executive. ${ }^{79}$ This did not, however, lead to the independence of courts because the Emperor appointed judges as a sovereign, and he reviewed cases at his Zufan Chilot without substantive or procedural legal restrictions. ${ }^{80}$

73 Judicial Administration Proclamation 323/1973, art 4 and 5, respectively.

74 Id., art 15. Aberra Jembere holds that the adoption of this statute had created ambivalence between those Governors and the Emperor adding fuel to the already brewing 'Revolution' as one of possible causes leading to ending the Imperial government. Aberra Jembere (1991), Agony in the Grand Palace: 1974 - 1982 (Shama Books, in Amharic) 33 -34.

75 Proc No 2/1942, supra note 42, art 3.

${ }^{76}$ Decree No 1/1942, supra note 46, art 10.

${ }^{77}$ Proc No 2/1942, supra note 42, art 23.

${ }^{78}$ Proc No 195/1962, supra note 67. Also see Civ. C., art 3347(1).

${ }^{79}$ See text for supra note 75.

${ }^{80}$ Howard supra note 54, 166; Zufan Chilot would later be incorporated into Proc 195/1962 supra note 67, without defined procedure. 


\section{Courts under the Military Government}

\subsection{The regular courts}

The military government introduced fragmented criminal law. A Special Penal Code was adopted and applied by a Special Courts-Martial. Accordingly, following the practice of former socialist and/or military dictatorships, the military regime created two categories of courts. ${ }^{81}$ The courts established by the Administration of Justice Proclamation No 52/1975, re-established the Woreda Court, the Awradja Court, the High Court and the Supreme Courts having criminal and civil jurisdictions in their respective local limits.

\subsection{The establishment of Special Courts-Martial}

In September 1974, the Provisional Military Government established itself as 'the government' and defined its powers. ${ }^{82}$ The PMAC then created the Special Courts-Martial and adopted the Special Penal Code to deal with past and prospective wrongs, including those that were alleged to have been committed by the officials of the Imperial regime. ${ }^{83}$

The Imperial ministers and high-ranking officials were detained since 26 April 1974, most of them voluntarily submitting on the same day with a strong conviction that they would be acquitted after fair trial. ${ }^{84}$ The detention continued until 8 September 1974. On 23 November 1974, however, the PMAC executed 60 (sixty) high-ranking Imperial Government Officials, without trial including the short-time president of the PMAC Government, Lt. General Aman Michael Andom ${ }^{85}$ was also killed on the same day in the course of an attempt to arrest him.

The Government Press Statement stated that other wrongdoers would "immediately be dealt with through the Special Courts-Martial" ${ }^{86}$ However, the PMAC criminal charge did not come forth within the period that was promised. The press briefings were only meant to calm the public. There

${ }^{81}$ Grzybowiski (supra note 26). Pereira, supra note 7.

82 Provisional Military Government Establishment Proclamation No 1 of 1974 ('Proc No 1/1974'). Definition of Power of the Provisional Military Administration Council and Its Chairman Proclamation No 2 of 1974 ('Proc No 2/1974').

${ }^{83}$ Proc No 7/1974, supra note 2, and Proc Ns 8/1974, supra note 34.

${ }^{84}$ Aberra, supra note 74, 18, 39- 43, 61.

85 'Serious Political Decision Taken by the Provisional Military Administration Council' Addis Zemen 26 November 1974 (Addis Ababa) 1, 7, 8.

86 'Objectives of the Dergue' (supra note 1). 'Serious Political Decision' (supra note $85)$. 
were even pleadings of the PMAC authorities with those prisoners to tell their families that they would be charged and tried sooner. ${ }^{87}$ The Court was supposed to be assisted by an Inquiry Commission whose investigation took longer, and it rather focused on the famine in Wollo than investigation of the alleged crimes. Further, there was no body nor institution that responded to the Commission's call for criminal allegation and evidence against the detainees. The Commission was finally abolished in mid-1977. ${ }^{88}$

The Special Courts-Martial that started hearing cases (after the termination of the Inquiry Commission) was presided by five judges who were military officers. It conducted hearings inside the Grand Palace in Zufan Hall, ${ }^{89}$ and very little record is available regarding the proceedings of the Court. The initial cases were against 12 individuals six of whom were acquitted by the Special Courts-Martial, ${ }^{90}$ two were sentenced to suspended sentence on two years' probation and the cases against four defendants were dropped. For Instance, Major Admassie Zeleqe was acquitted on 3 December 1975. ${ }^{91}$ Aberra Jembere recounts that there were people who were executed based on the decision of the Special Courts-Martial including one Colonel Hailu Regassa who was a judge in a Special Courts-Martial. ${ }^{92}$

The special criminal law was made retrospectively applicable $;^{93}$ it was applied by a Special Courts-Martial, Special Prosecutor and Special Registrar, appointed by the Head of State (the Dergue). ${ }^{94}$ The process was also governed by Special Criminal Procedure Code Proclamation No 9 of 1974. It was made equally applicable to both civilian and military personnel $;{ }^{95}$ and the decision of the court was final and non-appealable. ${ }^{96}$

\footnotetext{
${ }^{87}$ Aberra, supra note 74 at 99, 137.

${ }^{88}$ Id., 61.

${ }^{89}$ Id., 14.

${ }^{90}$ Lt. Colonel Adella Qitaw, Maj. General Girma Mulat, Major Admassie Zeleqe, Ato Teshome GebreMariam, Ato Gorfu GebreMedihin and Ato Aklilu BeteMariam. Id., 139 , the note.

${ }^{91}$ Ibid. Major Admassie demanded a copy of the judgement in order to report to the people of Harar -whom he had been representing in the Imperial Chamber of Deputies- that the charges were not as reported on the Radio. However, his release would be suspended'. Id., 139-40.

92 Id., 96, 97.

${ }^{93}$ Special Penal Code adoption Proclamation, preamble, para 11, art 2(1).

${ }^{94}$ Proc No 2/1974, supra note 83, art 3.

${ }_{95}$ Proc No 7/1974, supra note 2, art 2(2).

${ }^{96}$ Proc No 1/1974 (supra note 82) art 9. Proc No 7/1974 (supra note 2) art 10.
} 
The Special Penal Code criminalised certain conducts that were vaguely stated ${ }^{97}$ it increased criminal punishments and it introduced additional modes of punishments. ${ }^{98}$ Outside of Addis Ababa, the jurisdiction of the Special Courts-Martial were delegated to regular courts based on their specific jurisdictions. ${ }^{99}$

\subsection{The re-establishment of the special courts with civilian judges}

In 1981, there was legal revision. ${ }^{100}$ The Special Courts-Martial was replaced by a Special Court, established by Proclamation No 215/1981, to try cases based on the Revised Special Penal Code, and it was presided also by civilian judges. ${ }^{101}$ The Special Court had first instance court to try all cases arising out of the Revised Special Penal Code and an appellate court. ${ }^{102}$ Same as its preceding legislation, decisions of the Special Court that involved 'life imprisonment or death sentence [were] ... reviewed by the Head of State'. ${ }^{103}$

Article 22 of the Special Court Establishment Proclamation provided that the Special Court was the successor of the Special Courts-Martial with respect to any question arising from the decision of the latter. And, based on Article 21, pending cases were allowed to be decided by the court before which they were pending. The detainees in the Grand Palace were released; and the judges of the Special Courts-Martial were transferred to the Special Court. The Special Court began its work with new cases that mostly involved low profile offences. ${ }^{104}$

97 See, such as the provisions of article 35 - Offences against the Motto 'Ethiopia Tikidem', which is later dropped in the Revised Special Penal Code.

98 Proc No 8/1974 (supra note 34) preamble, paras 2 - 5, 8. Simeneh and Cherinet 'Governing' (supra note 18).

${ }^{99}$ Special Courts-Martial Establishment Proclamation, Special Penal Code and Special Criminal Procedure Code Proclamations Amendment Proclamation No 21 of 1975 ('Proc No 21/1975').

100 The Revised Special Penal Code Proclamation No 214/1981.

${ }^{101}$ Proc No 215/1981, supra note 29, art 22.

102 Id., arts 4, 5.

${ }^{103}$ Id., art 14.

${ }^{104}$ For instance, Maj. Teshager was charged with receiving birr 200; Const. Getachew was charged with receiving birr 500; and Deputy Comm. Abbe for receiving wristwatch, all of whom were later acquitted. Special Prosecutor v Major Teshager Assefa (10 February 1984, Crim File No 15/76, Special First Instance Court); Special Prosecutor v Const. Getachew Demissie and Deputy Commander Abbe Wodemichael (6 July 1983 Crim File No 31/75, Special First Instance Court). See text for (infra note 139) and (infra note 135), respectively. 
It should be noted that during the post-1974 period, the regular Woreda, Awradja, High and the Supreme Courts were re-established without any material change as per article 3(1) of Administration of Justice Proclamation No 52/1975. The benches that handled criminal charges applied the 1961 Criminal Procedure Code, and these regular courts operated parallel to the Special Courts.

\subsection{The re-establishment of the Supreme Court as per the 1987 PDRE Constitution}

The Constitution that was promised in 1974 was adopted after thirteen years in September 1987 as The Constitution of the People's Democratic Republic of Ethiopia which was used as a justification for the re-establishment of almost all justice institutions in a totally different ideological context. ${ }^{105}$ Chapter 14 of the Constitution created the judiciary as an autonomous state organ for the first time. Article 100(1) provided that 'judicial authority shall be vested only in one Supreme Court, courts of administrative and autonomous regions, and other courts established by law' which is further affirmed by Supreme Court Establishment Proclamation No 9/1987.

The Constitution further provided that the central objective of the courts would be 'safeguard[ing] the legally guaranteed rights, interests and freedoms of the state, mass organisations, other association and individuals' and inculcation of 'socialist legality'. ${ }^{106}$ The Government was interested in the collective interest and unscrupulous obedience to law than in individual rights and maintenance of the rule of law. The Supreme Court was made in charge of administration 'of all courts of the country' supervising their function. 107

The High Court and the Awraja Court were established by High Courts and Awraja Courts Establishment Proclamation No 24/1988. The High Courts were established in each autonomous and administrative region, ${ }^{108}$

105 Also, the military court and prosecution office were established by Military Court Establishment Proclamation No 10/987, Procuratorial Office Establishment Proclamation No 11/1987, respectively.

106 The Constitution of the People's Democratic Republic of Ethiopia ('PDRE Const') art 100(2). Proc No 9/1987 (supra note 29) art 3; High Courts and Awraja Courts Establishment Proclamation No 24/1988 ('Proc No 24/1988') art 4.

${ }^{107}$ PDRE Constitution, supra note 106, art 102.

108 'Administrative Regions' were designated as local administration in the PDRE Government; under the FDRE Government, they are referred to as 'Zones'. 
and the Awraja Courts were established in each Awraja. ${ }^{109}$ The jurisdictions of Woreda Courts were transferred to Awraja Courts. ${ }^{110}$ The Special Court was abolished and matters arising out of the Revised Special Penal Code came under the jurisdiction of the High Court. ${ }^{111}$ Appeals from such decisions were heard by the Supreme Court. ${ }^{112}$ The court structure had the Supreme Court at the top with cassation power; the High Court was entrusted with first instance and appellate jurisdictions and Awraja Court was at the bottom of the hierarchy. ${ }^{113}$

Judges were elected by the respective Shengos ${ }^{114}$ and their term was 'the same as the Shengo which elected them.' ${ }^{115}$ The President of the Republic had absolute power on the removal and replacement of the Supreme Court Judges. ${ }^{116}$ The President of the High Court would submit reports of activities of the High Court and the Awraja Court to the Ministry of Justice. ${ }^{117}$ The staff of these courts were considered part of the Ministry of Justice and the High Court and Awraja Court presidents administered the staff and prepared work program and budget of the Courts on behalf of the Ministry. ${ }^{118}$ These sub-constitutional rules which were given effect contradict with the PDRE Constitutional provision which stated that courts would be autonomous.

Moreover, the Supreme Court Establishment Proclamation had introduced the cassation procedure in the manner we know today -to correct fundamental error of law committed in a final judgement. ${ }^{119}$ Whether a particular case merits review by cassation was decided by the President of the Supreme Court or the Procurator General. ${ }^{120}$ However, the protest of the Procurator General against a certain decision was directly sent to the Cassation Division. ${ }^{121}$

\footnotetext{
109 Proc No 24/1988, supra note 106, art 3.

${ }^{110}$ Id., art 30(1).

${ }^{111}$ Proc No 9/1987, supra note 29, art 31(2) and 32(1), respectively.

${ }^{112}$ Id., art 33(2).

${ }^{113}$ Woreda Courts jurisdiction was transferred to Awraja Court. Id., art 30(1).

114 PDRE Constitution, supra note 106, art 101(1); Proc No 9/1987, supra note 29 are 11; Proc No 24/1988, supra note 106, art 12.

115 Ibid.

${ }^{116}$ Proc No 9/1987, supra note 29, art 13(3).

${ }_{117}$ Proc No 24/1988, supra note 106, arts 20(2), 21(1)(d).

${ }^{118}$ Id., arts 20(1)(a), 21(2)(a).

119 Id., arts 4(4) and 20. For in-depth discussion, see Yoseph Gebre Egziabher 'The Hearing of Final Judgment by the Supreme Court by way of Cassation: Another Right of Appeal Granted to Any One of the Parties?' (1989) 14 J Eth L 161.

${ }^{120}$ Proc No 24/1988, supra note 106, art 5(1), 24(7).

${ }^{121}$ Ibid.
} 


\subsection{Observations regarding the Special Courts-Martial and the Special Court}

The courts during the PMAC regime exhibit all the features of courts in nondemocratic regimes. ${ }^{122}$ The PMAC appears to have taken Chile's approach under Pinochet because the several similarities are more than accidents. Pinochet took power on 11 September 1973. In the first few years, the Government used the wartime military courts to try both civilian and military personnel. Because the Supreme Court expressed its support to the military regime, the Court allowed it to continue functioning until a new constitution was adopted in 1980 which restricted the power of the Supreme Court in reviewing the decisions of such military courts. ${ }^{123}$

Because the PMAC had been in a precarious situation, it established the Special Courts-Martial as soon as it came to power in September 1974. The Court had its seat in the Grand Palace trying imprisoned Imperial officials. Until the trial began, the Government even resorted to extra-judicial measure against the highest-ranking officials of the country. The Special CourtsMartial operated between 1974 and 1981, and the Special Court worked between 1981 and 1988 until it was finally integrated into the regular courts.

Two statements reflect the operations of the Special Courts-Martial. The first relates to in the preamble of the PMAC Proclamation while the second refers to official statements. With regard to the suspension of the Imperial Parliament, and preamble of the PMAC Proclamation reads:

[the] Parliament heretofore has been serving not the people but its members and the ruling elite and aristocratic classes, [] passing laws at various times intended to raise the living standard of its members, thereby using the high authority conferred on it by the people to further the personal interests of its members. ${ }^{124}$

Regarding the suspension of the 1955 Revised Constitution, the preamble stated that the Constitution 'was prepared to confer on the Emperor absolute powers; [...and] merely serves as a democratic façade for the benefit of world public opinion'. ${ }^{125}$ Lt. General Aman Andom, as the then Chairman of the PMAC, had (regarding the overthrow of the Imperial regime) stated that

\footnotetext{
${ }^{122}$ Moustafa and Ginsburg 'Introduction', supra note 25 at 2. Pereira, supra note 7.

${ }^{123}$ To diagnose the similarity of the PMAC regime to that of Pinochet's Government act of legitimising its authoritarianism through the law and the judicial process, see Hilbink, supra note 5, at 102-176.

${ }^{124}$ Proclamation No. 1/1974, supra note 82, preamble para 2.

${ }^{125}$ Id., preamble, para 3.
} 
'we have removed those enemies of Eritrea; they are awaiting their judgement.' 126

The PMAC, in its statement during the execution of 60 high ranking civil and military officials, had stated that 'other than those whose name is listed above to have been sentenced to death on political decisions, wrongdoers would be judged before the Special Courts-Martial in expeditious manner' ${ }^{127}$ Finally, the proclamation establishing the Special Courts-Martial stated its objective 'to expedite the administration of justice in an efficient, speedy and decisive manner'. ${ }^{128}$

Even though PMAC's statements criticized the previous regime in its acts of using the law as a means of achieving certain ends, which the PMAC considered illegitimate, the PMAC did the same in using the law and institutions as means of achieving its political ends it considered 'legitimate'. The judges of the Special Courts-Martial were army officers assigned by the PMAC.

Upon their release on 12 September 1982, PMAC representative had stated to the detainees that they were detained during the precarious period of the revolution and he related their release with the revolution's level of development. The certificate of release given to the detainees merely stated the reasons for their detention as: 'on suspicion they would impede the revolution'. ${ }^{129}$ These are indications that the PMAC used the criminal justice for political expediency. The argument is further strengthened by the fact at a stage when the government felt its steady grip on power, it abolished the Special Court and merged it with the regular courts.

\subsection{Selected cases of the Special Court}

Substantial number of the cases brought to Special Court were related to breach of trust. A few cases of bribe appeared before the court and other cases included charges such as perjury, ${ }^{130}$ political homicide, ${ }^{131}$ crimes

${ }^{126}$ ENA 'Opposing the Motto 'Ethiopia First' Tantamount to Opposing the Ethiopian People' Addis Zemen, 11 October 1974 (in Amharic) at 1.

127 'Serious Political Decision', supra note 85.

${ }^{128}$ Preambles of Proc No 7/1974, supra note 2 and Proc No 8/1974, supra note 34. Proc No 21/1975, supra note 99.

${ }^{129}$ Aberra, supra note 74 at 172-173.

130 Special Prosecutor v Taddese Bekele Gashu and Achamyeleh Belaye Ferede (8 August 1984, Crim File No 58/76, Special First Instance Court).

${ }^{131}$ Special Prosecutor v Getachew Balacha (12 October 1984, Crim App File No 55/76, Special Court of Appeal). 
against the state, ${ }^{132}$ and smuggling of money or property to foreign countries. ${ }^{133}$ The evidence presented in breach of trust cases were almost exclusively financial audit reports and the auditors had also appeared as witnesses; the evidence in bribe cases were exclusively witnesses who claimed to be victims.

The review of various cases reveals that the court was fair in the evaluation of the facts and the evidence to establish guilt or otherwise. In all cases reviewed here, the Special Court evaluated evidence professionally; shortcomings, if any, may only be professional errors. The court routinely applied the principle 'doubt favours the accused' both in terms of fact and in terms of law. In Haregewoin, ${ }^{134}$ the prosecution evidence was a financial audit report, and it was the basis of the charge. As the case progressed, the court had twice ordered further audit. All the three audit reports presented had different results. The Special First Instance Court acquitted the defendant on the ground that the evidence was doubtful. The Special Court of Appeals affirmed the decision of the lower court. ${ }^{135}$ In Lt. Tesfaye, ${ }^{136}$ the court held that the doubts in the facts and the evidence favours the accused.

Particularly impressive is the manner the Court dealt with confessions even better than the regular courts of the time. The Court, for various reasons, rejected confessions made as per articles 27(2) and 35 of the Criminal Procedure Code that shows the level of the independence of the court in the assessment of the facts. For instance, in Abdi Mohammed, et al., ${ }^{137}$ defendants had been charged with violation of article 2 of the Special Penal Code. Defendants were arrested in 1973 Ethiopian Calendar and their statements were recorded in 1975 EC. The Court reasoned that this confession was obtained after a long period and was not thus admissible. ${ }^{138}$

132 Seid Dirar Hamid v Special Prosecutor (26 November 1984, Crim App File No 65/76, Special Court of Appeal).

133 Asmerom Mengeste'ab v Special Prosecutor (25 May 1984, Crim App File No 40/76, Special Court of Appeal).

${ }^{134}$ Special Prosecutor v Haregewoin Menegesha (8 December 1983, Crim App File No 38/75, Special Court of Appeal).

${ }^{135}$ Likewise, Const. Getachew and Deputy Comm. Abbe (supra note 109) defendants were acquitted because the evidence is doubtful.

136 Special Prosecutor v Let. Tesfaye Atilabachew (21 March 1984, Crim App File No 29/75, Special First Instance Court).

137 Special Public Prosecutor v Abdi Mohammed Ibrahim, et al. (29 November 1983, Crim File No 62/75, Special First Instance Court).

${ }^{138}$ Defendants were acquitted without they being required to enter their defence as per art 142 of the Criminal Procedure Code. 
In Const. Abebe and Berhe, ${ }^{139}$ defendants were charged with bribery under article 20(1)(a) of the Revised Special Penal Code. The principal evidence presented was confession made to the police as per articles 27(2) and 35. Defendants proved they were coerced while they were under police custody at the Central Investigation Department. The court held 'a confession retracted, unless corroborated was not admissible'.

Although the court had maintained formal positivist view of law, it attempted to be consistent in its application. It always demanded the public prosecutor to prove each element constituting the crime unless expressly provided for in the law otherwise. The provisions of article 12 of the Special Penal Code dealt with breach of trust and were amended by Proclamation No 96/1976. ${ }^{140}$ The elements of the crime were (a) defendant is entrusted with government property; (b) such property is appropriated or alienated; and (c) it is appropriated or alienated to procure benefit for oneself or a third person. ${ }^{141}$

In Mulugeta, ${ }^{142}$ the court held that the provision of article 12 was amended in order to expedite the judicial process. If the public prosecutor proves the first two elements of the crime, the third element would be presumed. In Let. Goshime, ${ }^{143}$ the court held that the provisions of article 20(3) lowers the burden of the prosecutor; yet, the court indicated that this does not preclude the right of accused to defend (same as it had held in Crim File Nos 20/74 and 8/75). In both cases defendants were acquitted.

Often, defendants were acquitted after the hearing of prosecution evidence if the court believed that prosecution evidence was not sufficient to

${ }^{139}$ Special Prosecutor v Const. Abebe Kene'aa and Berhe Gebretatios (17 March 1983, Crim File No 25/75, Special First Instance Court).

140 Special Penal Code and Special Criminal Procedure Code Proclamations Amendment Proclamation No 96/1976.

Art 12(1) prohibits acts 'with intent to obtain or to procure for himself or to a third person ill-gotten gain; appropriates, alienates, hides, or undervalues or pts to his own or another's use a State or public property entrusted to him or to which he has access by reason of is powers or duties or commits such other acts'.

141 This is had become a common practice that it was held also in Special Prosecutor $v$ Deputy Commander Yihe'alem Mezgebu and Petty Officer Zenebe Shiferaw (15 April 1983, Crim File No 24/75, Special First Instance Court); Special Prosecutor v Oukube'ezgi Teklemariam (29 November 1983, Crim File No 50/75, Special Frist Instance Court).

142 Special Prosecutor v Mulugeta Girma (8 December 1982, Crim File No 15/74, Special First Instance Court).

143 Special Prosecutor v Lt. Goshime Wondimtegegn (26 March 1983, Crim File No 7/75, Special First Instance Court). 
enter conviction should there be no contrary evidence. This was clear in Oukube'ezgi, ${ }^{144}$ whereby the court, after hearing the prosecution evidence, acquitted the defendant without requiring him to enter his defence. ${ }^{145}$

The last point relates to judicial political statements. The criminal hearing had two levels - for the determination of guilt and where defendant is found guilty, the sentencing hearing. Often, political matters were reserved for the sentencing hearing which appears to have reflected on the character of the convict, as in the case of Mulugeta ${ }^{146}$ which involved a harsh sentence. In exceptional circumstances, where the matter is raised by the parties, the court would address it in the hearing on guilt as in the case of Assefa. ${ }^{147}$ In these and similar other cases, the court made unfounded and clearly political statements supporting the then socialist political ideology either in convicting the accused or in sentencing the convict.

\section{Federalisation of Courts}

\subsection{De facto federalisation of courts under the Transitional Government}

Regional Courts- The other important restructuring of the court is the federalisation of the courts. After the EPRDF came to power there was regionalisation of the country, and the Transitional Government of Ethiopia ('TGE') was constituted of several armed factions. ${ }^{148}$ The Members of the Council of the Transitional Government defined territories for election purposes. $^{149}$

The Council established three special committees, one of which was 'Committee for the Execution of Election'. ${ }^{150}$ In its reports to the Council, the Committee established a standard for demarcation of electoral districts

\footnotetext{
144 Supra note 141.

${ }^{145}$ Also see, Maj. Teshager (supra note 109); Asmerom (supra note 138).

${ }^{146}$ Supra note 142.

147 Special Prosecutorv Assefa Aynalem Mehanzel (7 June 1982, Crim File No 14/74, Special Frist Instance Court).

148 The seats are distributed in proportion to the size of their army. See for instance, 'Reports of the Defence and Security Committee 11 April 1992' (Addis Ababa).

149 See for instance, 'Minutes of the Sixteenth Regular Meeting of the Council of Representatives of the Transitional Government of Ethiopia, 3 October, 5 October, and 8 October 1991' (Addis Ababa).

150 'Minutes of the Fourth and Fifth Regular Meeting of the Council of Representatives of the Transitional Government of Ethiopia, 31 July - 01 August 1991' (Addis Ababa).
} 
based on ethnic identity. ${ }^{151}$ The several round of reports to the Council and the Council discussions ${ }^{152}$ resulted in the establishment of the administrative structure as per National/Regional Self-Governments Establishment Proclamation No 7/1992. ${ }^{153}$

This Proclamation established 'National Self-Governments' (states in the present sense) with legislative, executive and judicial powers. ${ }^{154}$ Each National Self-Government was required to have at least 7 core structures one of which was the judicial organ. ${ }^{155}$ Such judicial organ had territorial jurisdiction within its National Regional Government. ${ }^{156}$ Their material jurisdiction extended to matters not 'specifically assigned to the courts of the Central Transitional Government'. ${ }^{157}$ The statute recognised that all judicial power in any Self-Government would 'exclusively be vested in courts'. ${ }^{158}$ Such National Self-Government courts had one Superior Court and other lower courts, including Woreda court, established by the Council of such Self-Government. ${ }^{159}$

The Proclamation also provided for institutional and personal judicial independence of judges and courts, respectively, working language of the respective regional courts, and selection and appointment of judges, among others. ${ }^{160}$ Such claim of independence of the courts was further strengthened by the Independence of the Administration of Justice Proclamation No $23 / 1992$.

\footnotetext{
151 'Minutes of the Seventh Regular Meeting of the Council of Representatives of the Transitional Government of Ethiopia, 8 August 1991' (Addis Ababa).

152 'Minutes of the Twelfth Regular Meeting of the Council of Representatives of the Transitional Government of Ethiopia, 22, 27, and 29 August 1991' (Addis Ababa); 'Minutes of the Fifteenth Regular Meeting of the Council of Representatives of the Transitional Government of Ethiopia 17, 19, September and 1 October 1991' (Addis Ababa).

153 See particularly, 'Minutes of the Sixteenth Regular Meeting of the Council of Representatives of the Transitional Government of Ethiopia 03, 05 and 08 October 1991' (Addis Ababa).

${ }^{154}$ National/Regional Self-Governments Establishment Proclamation No 7/1992 arts 3, and 2(3). The demarcation of borders of woredas as they existed prior to 1974. Ibid art 6(2)(a). The reason for picking the year 1974 is not stated in the Minutes.

${ }^{155} \mathrm{Id}$., art 8(1)(c).

${ }^{156}$ Id., art $9(1)$.

${ }^{157}$ Id., art $10(9)$.

${ }^{158}$ Id., art 23.

${ }^{159}$ Id., arts 24, 34(3), 50.

${ }^{160} \mathrm{Id}$., arts $25-30$.
} 
Conspicuous Absence of Independent Judiciary and 'Apolitical' Courts in ... Ethiopia 405

Central Government Courts Constituting a Judiciary - Based on the de facto defined federal structure, the Central Government Courts were established by Central Government Courts Establishment Proclamation No 40/1993. The statute established the Central Supreme Court, the Central High Court and the Central First Instance Court of the TGE, ${ }^{161}$ and provided for both the material and local jurisdiction of the courts. ${ }^{162}$

The Central Supreme Court was given first instance jurisdiction on 'suits between two or more National/Regional Self-Governments'. ${ }^{163}$ Central Courts applied the Transitional Period Charter, International Treaties and laws of the Central Government. ${ }^{164}$ The bill of rights during the transitional period was the Universal Declaration of Human Rights. ${ }^{165}$ Where the subject in dispute involved National/Regional Self-Government law, such dispute was determined on the basis of such law, 'provided such laws shall not apply where they are inconsistent with the Charter, International Treaties or laws of the Central Government'. ${ }^{166}$

The Central Courts had the power to invalidate Central Government or National/Regional Self-Government laws, and the Central Supreme Court was given the power of certification. Judgements of the High Court were subject to review by the Central Supreme Court in its appellate jurisdiction. ${ }^{167}$ However, where a 'National/Regional Supreme Court renders or confirms life imprisonment or capital punishment' it would be subject to review by the Central Supreme Court on appeal. ${ }^{168}$

The Central Government Courts Establishment Proclamation, had provided that matters 'relat[ing] to a provision of a law with regard to which there is a fundamental difference in interpretation between divisions of the Central Supreme Court', such would be heard by a division 'constituted of by no less than five judges'. ${ }^{169}$ Such hearing was presided by the President or Vice-President, and the decision was 'binding. ${ }^{170}$

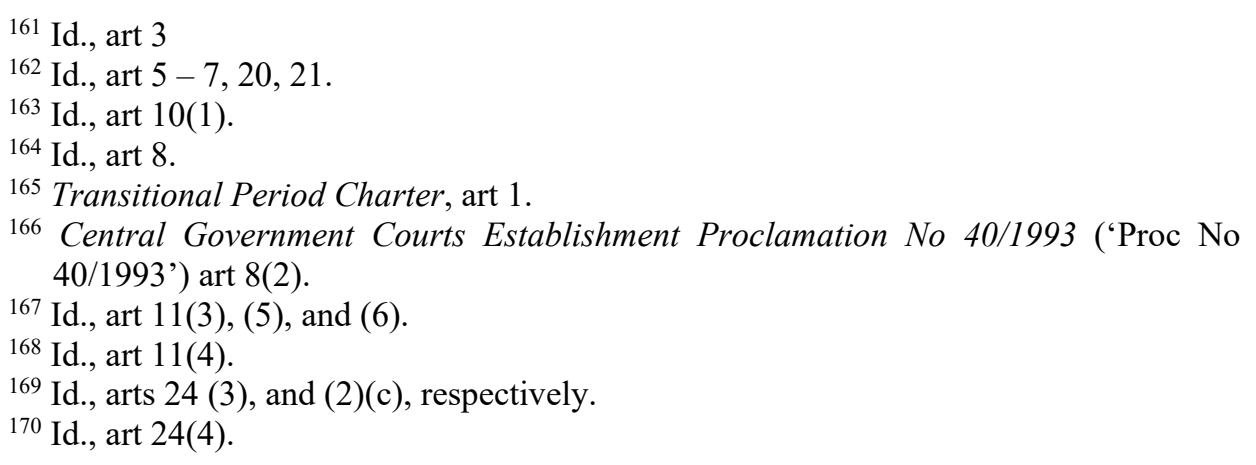




\subsection{Federal courts under the FDRE Constitution}

At the end of the transitional period, the Constitution of the Federal Democratic Republic of Ethiopia was adopted. The FDRE Constitution had envisaged an 'independent judiciary' entrusted with 'all judicial power'. ${ }^{171}$ The Constitution created a Federal Supreme Court, Federal High Court and Federal First Instance Court. The Federal Supreme Court was established by the Constitution and the establishment of the Federal High and First Instance Courts was left to the decision of the House of Peoples' Representatives. ${ }^{172}$ The Constitution also created State Supreme Courts, State High Courts and Woreda Courts, the establishment and jurisdiction of which were left to the respective States' Councils. ${ }^{173}$

The subsequent amendments to the Courts' Proclamation relate to the establishment of Federal High Courts in certain states, ${ }^{174}$ the hearing of certain cases by a single judge, ${ }^{175}$ and the reintroduction of the binding interpretative decision of the Cassation Division of Federal Supreme Court constituted by no less than five judges. ${ }^{176}$

However, the Federal Supreme Court was not adequately empowered. The courts in general have been timid both individually and institutionally to address criminal matters. The court has never determined its jurisdiction based on the Constitution; and it has been accepting whatever is determined by the lawmaker. Constitutional interpretation, even for the purpose of application, is fully avoided based on the justification that it is a power reserved to the House of Federation. ${ }^{177}$ Thus, constitutional provisions are rarely invoked and addressed before regular courts.

The court considers ordinary ministerial papers as part of criminal rules and at times modifying constitutional provisions. ${ }^{178}$ Rules are interpreted in a manner appeasing the executive beyond the call of duty. Administrative

171 Constitution of the Federal Democratic Republic of Ethiopia Proclamation No 1/1995 ('FDRE Const') art 78 and 79(1), respectively.

172 Id., art 78(2).

${ }^{173}$ Id., art 78(3).

${ }^{174}$ Federal High Court Establishment Proclamation No 322/2003.

${ }^{175}$ Federal Courts (Amendment) Proclamation No 138/1998.

176 Proc No 454/2005 (supra note 15).

177 Getachew Assefa (2010), 'All About Words: Discovering the Intention of Makers of the Ethiopian Constitution on the Scope and Meaning of Constitutional Interpretation' $24 J$ Eth L. See also, Sisay Alemahu Yeshanew (2008), 'The justiciability of human rights in the Federal Democratic Republic of Ethiopia'8 AHRLJ .

${ }^{178}$ Simeneh, 'Methods', supra note 37, at $104-107$. 
decisions regarding criminal matters that negatively impacted the individual, such as the registrars' refusal to open dossier as gatekeepers against the judge, unfairly expediting prosecution cases, such as giving preference to police and prosecutors' demands, and other matters require in-depth research. ${ }^{179}$

The party affiliation of judges, the strong executive, and other factors have been negatively impacting the performance of the court. ${ }^{180}$ Special prosecution agencies have also been adopted, such as the Federal Ethics and Anti-Corruption Commission and the Ethiopian Customs and Revenue Authority, ${ }^{181}$ which overwhelmed the court, always demanding to be treated differently, the prosecutors acting as though their case is more important than others'. The special influence of the intelligence and security forces which at times are reportedly influencing the process or outcomes, had a crippling effect on the court. ${ }^{182}$

The net effect of the lack of independence of the judiciary and the act of serving an authoritarian government beyond the call of duty, violates the commonly understood rules of interpretation thereby creating a sub-culture of subservient behaviour. ${ }^{183}$ Various decisions of the Cassation Division have been mere assertions very much in want of reasoning and explanation on the underlying theories of interpretation or any higher principle, such as justice, rule of law, the principles of coherence, and unity of legal system. ${ }^{184}$

The Federal High Court has been the forum for the prosecution and conviction of (a suspected) opposition. The waves of prosecution and the label under which such individuals are prosecuted differ. ${ }^{185}$ In the following section, however, only decisions of the Cassation Division are discussed.

179 The author is recounting personal experience.

${ }^{180}$ Assefa Fiseha (2015), 'Legislative-Executive Relations in the Ethiopian

Parliamentary System: Towards Institutional and Legal Reform' in Jaap de Visser,

Nico Steytler, Derek Powell and Ebenezer Durojaye (eds), Constitution-Building in Africa (Nomos) 248 -262.

181 They are all brought under the Federal Attorney General. Federal Attorney General Establishment Proclamation No 943/2016, art 22.

182 There were two documentaries broadcast on national television, after the TPLF led EPRDF was replaced by other members in May 2018, regarding violation of human rights by security forces which the court could not address.

${ }^{183}$ Simeneh 'Higher Norms', supra note 5.

${ }^{184}$ Ibid.

${ }^{185}$ At one moment there was a high rate of prosecution against All Amhara People's Organisation (AAPO) leadership; at another moment there was prosecution of alleged members of Oromo Liberation Front (OLF); and recently there were 


\subsection{Selected cases of the Cassation Division}

Jurisdiction of a cassation court in the present sense is recognised since 1987 to correct fundamental error of law ${ }^{186}$ and such decision relating to legal interpretation is binding on lower courts since 1993. ${ }^{187}$ The cassation jurisdiction of the Federal Supreme Court is constitutionally vested. The binding nature of the interpretative decisions are re-established in later proclamations.

The interpretative power of the Cassation Division does not include changing the law, either in wording or spirit, but to interpret the law in a manner that shades light on its application. Such may be made by elaborating the underlying theories or principles where such provision is vague or subject to potentially different interpretation and application. This is the core responsibility of the Cassation Division. Those decisions discussed in this section, however, significantly deviate from the clear provision of the law, and they rather negatively impact individual rights thereby apparently favouring the state's case.

\subsubsection{Binding interpretative decisions relating to bail}

Bail is a constitutional right although its scope is frequently changed and arguable. The discussion is made based on the provisions of article 75 of the Criminal Procedure Code which provides that ' $[\mathrm{w}]$ here bail has been refused by a court, the accused may apply in writing within twenty days against such refusal to the court having appellate jurisdiction.' The contents of this provision are sufficiently clear. The condition of appeal against a decision on bail is when it is denied, and it is the accused that may lodge such appeal. However, the Cassation Division has rendered binding interpretative decisions on bail matters deviating from the clear provisions of the law thereby nullifying the protection that is accorded to the accused.

In Habtamu Deju ${ }^{188}$ petitioner was charged with telecom fraud, and the Federal High Court granted him bail. The Public Prosecutor appealed to the Federal Supreme Court which reversed the decision of the High Court. The cassation petition was against such decision of the Supreme Court on the ground that the public prosecutor cannot appeal against the granting of bail.

prosecution for alleged membership of the Patriotic Front, or as Islamic

Fundamentalism.

${ }^{186}$ Proc No 9/1987, supra note 29, preamble, para 4, art 4(4).

187 Proc No 40/1993, supra note 166, art 24(4). Proc No 195/1962, supra note 67, art 15.

${ }^{188}$ Habtamu Deju v Federal Public Prosecutor (17 July 2017, Cass File 110969 in 18 Decisions of the Cassation Division of the Federal Supreme Court). 
The Cassation Division held that even though the provision is coined in a manner that an accused who is denied bail may appeal against such decision, it should not be read as a contrario prohibition of appeal against granting of bail. The Cassation Division rendered a similar decision in Hassen Abdal. ${ }^{189}$

One can see that the court was very much influenced by the politics of the day. The Anti-Corruption Special Procedure and Rules of Evidence Proclamation No 236/2001 did not prohibit bail. However, it was soon amended, and the law provided that a person suspected of 'a corruption offence shall not be released on bail. ${ }^{190}$ When it was finally revised, the Revised Anti-Corruption Special Procedure and Rules of Evidence Proclamation No 434/2005, article 5(1) provided that both the public prosecutor and the suspect have 'the right to appeal' against a decision on bail.

Both cases discussed above are not corruption cases, and they involve charges for violation of special penal legislation. The provisions governing corruption cases have impact on other crimes when they are misread as expression of 'state interest' regarding bail in criminal matters.

The other aspect of bail in corruption offences relates to the provisions of article 4(1) of the Special Procedure. It provides that a person arrested or 'charged with a corruption offence punishable [...with] more than 10 years may not be released on bail' [emphasis added]. The obvious understanding of this provision is that the legal minimum sentence for an accused to be denied bail should be ten years imprisonment.

In Lalu and Kemal, ${ }^{191}$ respondents were charged with aggravated breach of trust in violation of article 676 of the Criminal Code which imposes 5 to 25 years of rigorous imprisonment. The Zonal (High) Court denied them bail. On appeal, the State Supreme Court granted respondents bail which was affirmed by the State Supreme Court Cassation Division. The courts held that the legal minimum sentence that justifies denial of release on bail is 10 years imprisonment while the crime defendants were charged with is punishable with 5 years' imprisonment.

${ }^{189}$ Hassen Abdal v Federal Public Prosecutor (2 November 2015, Cass File No 112725, in 19 Decisions of the Cassation Division of the Federal Supreme Court).

190 Anti-Corruption Special Procedure and Rules of Evidence (Amendment)

Proclamation No 239/2001, art 2(2).

191 SNNRS Ethics and Anti-Corruption Commission v Lalu Seid Akelta and Kemal Hussien Dalbo (4 August 2011, Cass File No 63344, in 12 Decisions of the Cassation Division of the Federal Supreme Court). 
The case was brought to the Federal Supreme Court Cassation Division which made a binding interpretative decision on the provisions of article 4(1). According the Cassation Division's decision, there are three things to be taken into consideration. The first consideration was related to the special nature of the procedure and the intended objective of the lawmaker. In this regard, the court held that this element is stated in the preamble of the statute. The second and third considerations were, respectively, the exposé des motifs (Hateta Zemikniyat) for the statute, and interpreting the rule in a manner to make it effective.

It finally held that the interpretation of the State Courts by considering the legal minimum punishment would nullify such intended objective. It held that the matter relating to bail should be determined by taking the maximum punishment of the crime the accused is charged with. Because several of those crimes are punishable with imprisonment between 7 and 15 years ${ }^{192}$ unless aggravated, this interpretation makes the provisions of article 4(1) unhelpful. In all these cases, the court never referred to the provisions of the Constitution while the subject clearly involves constitutional rights.

\subsubsection{Interpretative decisions relating to objection to charge}

Objection to charge is an important procedure helping the court sort out legal matters at early stage of the process. Because objections are based on legal issues, often they could be resolved merely based on the records of the court. In Teoum, ${ }^{193}$ the petitioner was charged under article 408(2) of the Criminal Code for taking bribe Birr 2,000 while being manager of a company, not functional then. He raised objection that the conduct is covered under article 408(1). Based on such objection, the Federal High Court ruled that the benefit obtained, the harm caused, and the motive are not grave; thus, the charge should be drawn up under article 408(1).

Contrary to article 184(b) of the Criminal Procedure Code, the Prosecutor appealed against such ruling and the Federal Supreme Court held that those matters may be determined only after hearing the prosecution evidence. Therefore, the Court was required to proceed with the case maintaining the charge as drawn up by the prosecutor. The defendant had submitted cassation petition to the Federal Supreme Court Cassation Division, unfortunately not on the procedural matters but on the substance of the case.

\footnotetext{
${ }^{192}$ Such provisions are maintained in the Corruption Crimes Proclamation No $881 / 2015$.

${ }^{193}$ Teoum Tekea Gebrai v FEACC (Dire Dawa) (27 January 2015, Cass File No 103452 in 17 Decisions of the Cassation Division of the Federal Supreme Court).
} 
The Cassation Division affirmed the decision of the Supreme Court, that those matters may be determined only after hearing prosecution evidence.

Likewise, in Addis, ${ }^{194}$ petitioner was charged with aggravated breach of trust contrary to 676(1) of the Criminal Code which is punishable with 5 to 15 years rigorous imprisonment. Defendant argued that this legal provision is replaced by article 31(1) of the Corruption Crimes Proclamation No $881 / 2015$, which embodies a punishment range from with 3 to 7 years of imprisonment. ${ }^{195}$ Obviously, seen in light of article 4 of the special procedure, this newly adopted provision makes the offence bailable as it is punishable with less than 10 years imprisonment. The Federal High Court then granted bail to the defendant.

The Public prosecutor appealed against the decision of the High Court. The Supreme Court held that article 37 of the Corruption Crimes Proclamation provides 'corruption cases that are committed before effective date of this Proclamation shall be finalised in accordance with the provisions of the Criminal Code.' The proceedings were progressing under article 676(1) as stated in the charge. The Supreme Court held that these provisions do not allow petitioner to be released on bail. Determination of whether the conduct is covered under article 31(1) of the new proclamation would be made only after evidence is heard and the facts are established. The Cassation Division affirmed the decision of the Supreme Court.

The issues raised in both cases relates to law, not facts. However, they are corruption cases prosecuted by the Federal Ethics and Anti-Corruption Commission. By indirectly denying bail to petitioners, the court met the demands of the public prosecutor. However, those decisions of the Cassation Division muted the significance of objections to charges for good.

\subsubsection{Interpretative decisions relating to administrative decisions' 'finality clause'}

The FDRE Constitution provides that '[j] udicial Powers, both at Federal and State levels, are vested in the courts. ${ }^{196}$ It further provides that '[e]veryone has the right to bring a justiciable matter to, and to obtain a decision or judgment by, a court of law or any other competent body with judicial power. ${ }^{197}$ There is no any exception to these rules. The explanatory note to

\footnotetext{
${ }^{194}$ Addis Walelign Belay v FEAAC (16 November 2015, Cass File No 117383 in 19

Decisions of the Cassation Division of the Federal Supreme Court).

${ }^{195}$ Further, art 36(1) expressly repeals the provisions of the Crim. C., art 676.

${ }^{196}$ Id., art 79(1).

${ }^{197}$ Id., art 37(1).
} 
the draft constitution states that disputes may be resolved both by the court and administrative organs which would ultimately come to court. ${ }^{198}$ Stated otherwise, this judicial power cannot be limited by the lawmaker nor can such judicial power be given to a non-judicial organ to the exclusion of the regular courts.

There are instances where the lawmaker establishes administrative tribunals or boards for review of administrative decisions. For instance, the Social Security Authority is given the power to 'implement social security laws, regulations and directives', among others. ${ }^{199}$ This involves administrative decision-making and the statute has established an appeal tribunal to review and give a 'final decision'. ${ }^{200}$ The Federal Supreme Court Cassation Division has abdicated its responsibilities in some cases, by holding that the decision is 'final', while in others by holding that if such judicial power is given to another organ, courts are precluded from entertaining such action.

In Birhanu and Kebede, ${ }^{201}$ the respondents requested the Federal First Instance Court to review an administrative decision, and the court rejected the pleading for want of jurisdiction. The Federal High Court affirmed the decision. The Cassation Division of the Federal Supreme Court held that the power to decide on such matters is reserved to the Social Security Authority Appellate Tribunal as per Proclamation No 38/1996 article 11(4). The Court further held that as stipulated under article 4 of the Civil Procedure Code, if such judicial power is given to another organ, courts are barred by such laws and, thus, they do not have jurisdiction.

The contents of article 4 of the Civil Procedure Code appear to have already been established; so is the finality clause of statutes. The lawmaker has revised the decisions of the Cassation Division by at least allowing appeal on matters of law. ${ }^{202}$ However, the Cassation Division further

\footnotetext{
198 'Brief Explanatory Memorandum to the Draft Constitution Certified by TGE Council of Representatives 28 October 1994' (in Amharic) 94- 95.

${ }^{199}$ Social Security Authority Establishment Proclamation No 38/1996 art 5(1).

${ }^{200}$ Id., art 11(1).

${ }^{201}$ Social Security Authority v Birhanu Hiruy and Kebede Gebremaryam (26 December 2005, Cass File No 18342, Federal Supreme Court Cassation Division, unpublished).

202 Public Servants Pension Proclamation No 714/2011, article 56(4); Aberra Kidane $v$ Gamo Goffa Zone Abra Minch Social Security Branch Office (19 October 2012, Cass File No 72928 in 15 Decisions of the Cassation Division of the Federal Supreme Court); Public Servants Social Security Agency v Aberra Boken, et al. (02 November 2012, Cass File No 80964, 15 Decisions of the Cassation Division of the Federal Supreme Court).
} 
recognised the quasi-judicial power of Privatisation Agency Board in Spouse and Heirs of Wasihun Mekonnen ${ }^{203}$ and Heirs of Mohammed Hussien. ${ }^{204}$

In Woldai, et al. ${ }^{205}$ petitioners were employees of the Ethiopian Revenue and Customs Authority. They petitioned the Civil Service Commission, protesting the termination of their employment contract; the Commission rejected their appeal. The decision of the Commission was based on Council of Ministers Regulations No 155, article 37(1) which provides that the Director General may dismiss any employee whom he suspects of corruption without following the regular disciplinary process. Sub-article (2) further provides that '[a]ny employee of the Authority, who has been dismissed from duty by the General Director, may not have the right to reinstatement by the decision of any judicial body.' This decision of the Commission was affirmed by the Federal Supreme Court in its appellate division. This cassation petition was against these decisions.

The Cassation Division, invoking both the provisions of article 4 of the Civil Procedure Code and article 37(1) of Regulations No 155, held that it is not 'justiciable matter'; it can at best be said exercise of administrative prerogative. Nine years later, the Council of Constitutional Inquiry in its 13 February 2019 session held that this provision of the Regulations is unconstitutional. The difference does not lie in the content of the law, but is clearly attributable to change in political power.

\section{Developments Relative to Federal Courts Proclamation No 1234/2021}

As part of the justice reform effort, various proclamations relating to courts are replaced by Federal Courts Proclamation No 1234/2021. The new statute reaffirms three fundamental constitutional assumptions regarding the role of courts: (i) judicial power is vested in the courts; (ii) everyone has a right to bring a justiciable matter to court and obtain a judgment; and (iii)

203 Spouse and Heirs of Wasihun Mekonnen v Government Houses Agency (2 November 2012, Cass File No 43511 in 14 Decisions of the Cassation Division of the Federal Supreme Court).

204 Heirs of Mohammed Hussien v Government Houses Agency and Haileyesus Gebremedihin (4 February 2011, Cass File No 37964 in 12 Decisions of the Cassation Division of the Federal Supreme Court).

${ }^{205}$ Woldai Zeru, et al. v Ethiopian Customs and Revenue Authority (24 May 2011, Cass File No 51790 in 12 Decisions of the Cassation Division of the Federal Supreme Court). 
courts have inimitable role in enforcing the rules of law and protection of human and democratic rights. ${ }^{206}$

The statute, further contains two substantive provisions; first, article 3(1)(a) provides that Federal Courts have jurisdiction on "cases arising under the Constitution.' Article 6(1)(a) further provides that courts settle cases before them on the basis of the Constitution, among others. Second, article 11(3) provides that 'the Federal High Court may render decisions [] to protect justiciable human rights. ${ }^{207}$ It is further provided under article 3(3) that in rendering judgments, the courts 'shall interpret and observe the provision of the Constitution pursuant to articles 9(2) and 13(1) of the Constitution. ${ }^{208}$ Based on these provisions the Federal High Court has established a division to deal with constitutional disputes.

Some might want to believe this division of the High Court, in its endeavour to resolve constitutional disputes, would engage in 'constitutional interpretation'. However, these provisions of the Federal Courts Proclamation do not change the status quo for the following reasons. First, the statute cannot grant jurisdiction to courts more than what is vested in them by the Constitution. What the Constitution grants to the courts is constitutional disputes short of issues that challenge the constitutionality of laws, which is reserved to the House of Federation and the Council of Constitutional Inquiry. ${ }^{209}$ To that extent, the courts cannot hold the lawmaker accountable when it exceeds its constitutional power.

Second, consequent to the above argument, the concepts and phrases 'constitutional dispute' and 'constitutional interpretation' have different connotation in the Constitution and the Courts Proclamation. For the purpose of defining jurisdiction of the Council of Constitutional Inquiry, the Constitution uses the phrase 'constitutional dispute' in reference to petitions challenging constitutionality of a statute; and 'constitutional interpretation' is used in reference to decisions nullifying a sub-constitutional norm found to have contradicted the Constitution. ${ }^{210}$ The Courts Proclamation does not use these phrases. However, conceptually, constitutional disputes in the Proclamation seem to refer to claims based on constitutionally recognised

\footnotetext{
${ }^{206}$ Federal Courts Proclamation No 1234/2021, preamble, paras 1- 3.

${ }^{207}$ It also includes public interest litigation, art 11(4).

208 Those provisions deal with the obligation state organs to respect and enforce the Constitution.

${ }^{209}$ FDRE Const., arts 62(1) and 84(1), (2).

${ }^{210} \mathrm{Id}$., arts 84(2), (3), respectively.
} 
rights, and constitutional interpretation appears to refer to giving content to those constitutional provisions. ${ }^{211}$

Third, the fact that such jurisdiction emanates from the provisions of the Courts Proclamation (which appears to be subject to change by the lawmaker) does not change the predicaments of the court. It should be noted that the Court is not granted the power to nullify any statute or provision of any sub-constitutional norm; rather it is merely encouraged to utilize constitutional provisions to settle disputes based on the provisions of the Constitution.

\section{Conclusion and the Way Forward}

The judiciary is the third branch of a state holding the other two branches accountable for their actions. Ethiopia's courts are mostly established and reestablished by sub-constitutional norms. Even when it is established by the respective constitutions, the court is not given such power to hold the other branches accountable. The power and jurisdiction of courts is redefined by the sub-constitutional norms. The court is not challenging the subconstitutional norms that define (restrict) its powers. The court does not want to appear addressing political issues either. It desires to present itself as a 'non-political' institution dealing purely with legal matters. The court always complies with what 'the law' says.

Although the instrumental nature of the court is clearly seen in the PMAC period when the Special Courts-Martial was created, the attempt was already there in the imperial period, by controlling the court from the top at Zufan Chilot. Even when the court is created as an independent institution under the FDRE Constitution, its jurisdictions were defined by sub-constitutional rules. Thus, the Federal Supreme Court in its binding interpretative decision, merely declares its judgement based on jurisdictions given to it and rules made by the lawmaker even when they appear to contradict the Constitution. Even if the new Courts Proclamation makes reference to 'constitutional disputes' and 'constitutional interpretation', it does not change the circumstances of the courts.

The way forward, evokes the concerns in Lisa Hilbink's observiations highlighted in Section 2 regarding the regime related and attitudinal factors that render courts mere extensions of the executive. The required attitudinal reform hinges upon the level of competence, commitment and integrity of

${ }^{211}$ Courts Proclamation, arts 6(1)(a) and 11(3), respectively. 
judges so that they can focus on rule of law far beyond the black letter reading of the laws.

With regard to regime related hegemony, prospective Ethiopian laws should go beyond formal recognition of judicial independence and create the objective conditions thereof. This, inter alia, requires (i) constitutional amendment to entrust courts with the power of interpreting the Constitution, and (ii) entrench judicial review of administrative decisions by enhancing the commendable beginning that is made under recent law reforms. ${ }^{212}$

Addressing the challenges of hegemony against the judiciary thereby effectively ensuring judicial independence thus require the amendment of the Constitution in a manner that puts the court at par with the executive and the legislator to hold both accountable to their constitutional limits. Until such time the constitution is amended, the chairperson and the deputy chairperson of the Council of Constitutional Inquiry are the de facto president and the vice-president of the Federal Supreme Court. The Council has been advising the House of Federation in a manner that would not help the courts. The recent example can be the Witness Protection Proclamation, an obvious unconstitutional provision that is maintained as constitutional by the House of Federation. ${ }^{213}$ Therefore, in interpreting the Constitution, a path that would encourage the court to indulge more into constitutional interpretation is indispensable.

${ }^{212}$ See for example, the fourth section titled 'Judicial review of directive and administrative decisions' (Articles 48-57) of the Federal Administrative Procedure Proclamation No. 1183/2020.

${ }^{213}$ Federal Public Prosecutor v Getachew Assefa Aberra, et al (23 defendants) (Federal High Court, Crim F No 238040). 


\section{Cited References}

Aberra Jembere (1991). Agony in the Grand Palace: 1974 - 1982 (Shama Books, in Amharic)

Assefa Fiseha (2015). 'Legislative-Executive Relations in the Ethiopian Parliamentary System: Towards Institutional and Legal Reform' in Jaap de Visser, Nico Steytler, Derek Powell and Ebenezer Durojaye (eds), Constitution-Building in Africa (Nomos)

Barak, Aharon (2006). The Judge in a Democracy (Princeton UP)

Barak, Aharon (2012). Proportionality: Constitutional Rights and their Limitations (Doron Kalir tr, Cambridge UP

Engelking, W (2019). The Political Character of the Judiciary: Schmitt, Kelsen and the Polish Constitutional Tribunal' in Belov, M (ed), The Role of Courts in Contemporary Legal Orders (Eleven International Publishing)

Esubalew Belay Fanta (2016). 'The British on the Ethiopian Bench: 1942 - 1944.' 16 Northeast African Studies 67

Getachew Assefa (2010). 'All About Words: Discovering the Intention of Makers of the Ethiopian Constitution on the Scope and Meaning of Constitutional Interpretation', 24 J Eth L 139

Graver, Petter Graver (2015). Judges Against Justice: On Judges When the Rule of Law is Under Attack (Springer)

Grzybowiski, Kazimierz (1960). 'Main Trends in the Soviet Reform of Criminal Law', 9 Am Univ LR 93

Hilbink, L (2007). Judges Beyond Politics in Democracy and Dictatorship: Lessons from Chile (Cambridge UP)

Howard, William E H (1955). Public Administration in Ethiopia: A Study in Retrospect and Prospect (JB Wolters)

Mahteme Selassie Woldemeskel (1942 EC), Zikre Neger, Second Ed.

Marein, N (1954). The Ethiopian Empire - Federation and Laws (Vurtheim and son)

Merse'Hazen WoldeQirqos (2008 EC). The Beginning of the Twentieth Century: Memories of My Eventful Days: From What I Saw and Heard $1896-1922,3^{\text {rd }}$ ed (Addis Ababa University Press, in Amharic)

Moustafa, T and Ginsburg (2008). T 'Introduction: The Functions of Courts in Authoritarian Politics' in Ginsburg, T and Moustafa, T, Rule by Law: The Politics of Courts in Authoritarian Regimes (Cambridge UP)

Pereira, AW (2008). 'Of Judges and Generals: Security Courts under Authoritarian Regimes in Argentina. Brazil, and Chile' in Tom Ginsberg and Tamir Mustafa (eds), Rule by Law: The Politics of Courts in Authoritarian Regimes (Cambridge UP)

Simeneh Kiros Assefa (2020). 'Limiting Criminalisation Power of the State in Ethiopia' ( $\mathrm{PhD}$ dissertation submitted to Addis Ababa University Law School, unpublished) 
Simeneh Kiros Assefa (2020). 'Non-Positivist 'Higher Norms' and Formal 'Positivism': Interpretation of Ethiopian Criminal Law' 14 Mizan LR 51

Thomas, EW (2005). The Judicial Process: Realism, Pragmatism, Practical Reasoning and Principles (Cambridge UP)

Wintgens, LJ (2002). 'Legislation as an Object of Study of Legal Theory:

Legisprudence' in Wintgens, LJ (ed), Legisprudence: A New Theoretical Approach to Legislation (Hart Publishing)

Wojciech Engelking (2019). 'The Political Character of the Judiciary: Schmitt, Kelsen and the Polish Constitutional Tribunal' in Martin Belov (ed), The Role of Courts in Contemporary Legal Orders (Eleven International Publishing).

Zamboni, Mauro (2008). Law and Politics: A Dilemma for Contemporary Legal Theory (Springer) 